\section{Kidney \\ Blood Pressure Research}

Review

\title{
Endothelial Progenitor Cells and Kidney Diseases
}

\author{
Abdullah Ozkok ${ }^{\mathrm{a}} \quad$ Alaattin Yildiz ${ }^{\mathrm{b}}$ \\ aUniversity of Health Sciences, Umraniye Training and Research Hospital, Department of Nephrology, \\ Istanbul, 'Istanbul University, Istanbul Faculty of Medicine, Department of Nephrology, Istanbul, Turkey
}

\section{Key Words}

Endothelial progenitor cells $\cdot$ Cardiovascular disease - Acute kidney injury $\cdot$ Chronic kidney disease $\bullet$ Glomerulonephritis $\bullet$ Sepsis $\bullet$ Renal transplantation $\bullet$ Microvesicles $\bullet$ Atherosclerosis

\begin{abstract}
Endothelial progenitor cells (EPC) are bone marrow derived or tissue-resident cells that play major roles in the maintenance of vascular integrity and repair of endothelial damage. Although EPCs may be capable of directly engrafting and regenerating the endothelium, the most important effects of EPCs seem to be depended on paracrine effects. In recent studies, specific microvesicles and mRNAs have been found to mediate the pro-angiogenic and regenerative effects of EPCs on endothelium. EPC counts have important prognostic implications in cardiovascular diseases (CVD). Uremia and inflammation are associated with lower EPC counts which probably contribute to increased CVD risks in patients with chronic kidney disease. Beneficial effects of the EPC therapies have been shown in studies performed on different models of CVD and kidney diseases such as acute and chronic kidney diseases and glomerulonephritis. However, lack of a clear definition and specific marker of EPCs is the most important problem causing difficulties in interpretation of the results of the studies investigating EPCs.

\section{Introduction}

Endothelial progenitor cells (EPCs) are stem cells that play major role in the maintenance of vascular integrity and repairment of endothelial damage [1,2]. EPC deficiency and dysfunction may contribute to increased risk of cardiovascular disease (CVD) observed in patients with chronic kidney disease (CKD) [3-6]. Furthermore, EPCs may also be important in the pathogenesis of various kidney disorders including ischemic acute kidney injury (AKI), sepsis, CKD, glomerulonephritis, acute and chronic rejection in patients with renal 


\section{Kidney Blood Pressure Research}

Ozkok et al.: EPCs and Kidney Diseases

transplantation (RT). Herein we aimed to summarize the possible effects of EPCs in CVD and kidney diseases. Investigative therapeutic modalities using EPCs were also discussed.

\section{Basic Concepts about EPCs}

Vasculogenesis in adult life: emergence of EPCs

Until recently, new vessel formation in adult life have been considered to be through "angiogenesis" by sprouting of endothelial cells from pre-existing blood vessels. However, during embryonic development, stem cell-mediated new vessel formation is called "vasculogenesis". In the light of new evidences, vasculogenesis has been shown to occur also in adult life. The first evidence of postnatal neovascularization was demonstrated by Asahara et al. [7]. In this study, CD34+ and fetal liver kinase-1+ (Flk1+) (vascular endothelial growth factor receptor: VEGFR) progenitor cells isolated from the peripheral blood were shown to incorporate into the sites of ischemia in an immunodeficient mice model with hindlimb ischemia. The term EPC was first used in this study and EPCs were suggested to be useful for collateral vessel growth in ischemic tissues.

\section{Definition of EPC}

EPCs are defined as non-endothelial cells that are capable of differentiating into endothelial cells. EPCs have characteristically two features: clonal expansion and stemness (ability to proliferate and resistance to stress) [8]. However, in experimental point of view, EPCs are frequently defined as mononuclear cells that are: 1) able to adhere to matrix molecules such as fibronectin and 2) double positive for acetylated low-density lipoprotein (acLDL) and Ulex europaeus agglutinin (UEA-1) lectin in cell culture studies [7].

Cell surface markers are also used to characterize EPCs in an increasing frequency however a single specific marker or combinations of markers for EPCs have not yet been identified. Most commonly used markers of EPCs include CD34, VEGFR-2 and CD133. These markers are usually used in double (CD34+/VEGFR2+, CD133+/VEGFR2+) or triple (CD34+/CD133+/ VEGFR2+) combinations. Lack of a specific marker, scarcity of EPC in the circulation and the presence of several common characteristics between EPCs and other hematopoietic and mature endothelial cells cause difficulties in interpretation of the results of the studies investigating EPC [9].

Types of EPCs: early and late EPCS

Two different populations of EPCs named as early and late EPCs have been suggested according to time needed for cultivation. "Early EPCs" (or colony-forming unit-endothelial cells: CFU-ECs) grow in cell culture in 4-7 days however "late EPCs" (or endothelial colonyforming cells: ECFCs) appear in 14 to 21 days in culture [10].

Early EPCs have limited capacity to proliferate and these cells indirectly induce angiogenesis in 3 ways: 1 ) by arranging the perivascular microenvironment by secreting paracrine factors $[11,12]$; 2 ) by secreting vasomodulatory microvesicles containing microRNAs (miR-126 and -296) [13]; 3) by communicating with mature endothelial cells by microtubular organelles (called nanotubes) [14]. Thus this type of EPC is sometimes named as "hematopoietic cells with proangiogenic activity". In contrast, late EPCs have high capacity of proliferation and they directly engraft into the injured site and regenerate into mature endothelium $[11,15]$. Although early and late populations of EPCs have different ways of function, both of these cell types lead to enhanced neovascularization during hindlimb ischemia $[11,16,17]$. In fact, early and late EPCs may act together and support each other in normal vascular physiology $[18,19]$.

In the study by Patschan et al., effects of early and late EPCs were compared in an ischemic AKI model [20]. Late EPCs were capable of reducing interstitial fibrosis in the mid- to longterm however peritubular capillary loss could not be prevented. In this study, late EPCs were 


\section{Kidney Blood Pressure Research}

not as efficient as early EPCs in preventing mice from ischemia-induced AKI. Although some subsets of EPCs may be capable of directly engrafting and regenerating endothelium, the most important effects of EPCs seem to be depended on paracrine effects.

Paracrine effects of EPCs: extracellular vesicles

Extracellular vesicles (EV) are small membrane particles that play important roles in cellular communication through transportation of various molecules such as proteins and micro-RNAs [21]. EVs can be divided into 2 groups: microvesicles and exosomes. Microvesicles are of 100- to 1000-nm diameter and they are formed from the plasma membrane through direct shedding. Exosomes are smaller than microvesicles with a diameter of 40- to 100$\mathrm{nm}$ which are released by exocytosis [22]. EVs secreted from EPCs have previously been reported to activate angiogenesis by transfer of mRNAs to mature endothelial cells leading to prevention form ischemic AKI $[13,23]$. In a rat model of ischemia-reperfusion injury, possible effects of EPC-derived-microvesicles on prevention of AKI have been investigated [13]. Microvesicles were found to contain microRNAs (namely microRNA-126 and microRNA-296) that modulate proliferation, angiogenesis and apoptosis. After intravenous injection, these microvesicles were found to localize to peritubular capillaries and tubular cells and enhance tubular cell proliferation and decrease leukocyte infiltration leading to protection from AKI. Furthermore, these microvesicles halted the progression of CKD by inhibiting glomerulosclerosis and tubulointerstitial fibrosis. In this study, total microRNA depletion by Dicer knockdown and RNase digestion diminished the protective effects of EPC-derived microvesicles. In another study by Cantaluppi et al. [24], EVs were injected intravenously to rats with anti-Thy1.1 glomerulonephritis and these EVs were shown to have protective effects by amelioration of mesangial injury caused by antibody and complementmediated mechanisms.

Late EPCs may have also paracrinic effects by the way of exosomes [25, 26]. In the study by Vinas et al. [25], infusion of exosomes (enriched in miR-486-5p) derived from ECFC led to functional and histologic protection in a mice model of ischemic AKI. In a study by Burger et al. [26], effects of ECFCs and their EV were investigated in an ischemic AKI model. EPCderived exosome injection was found to decrease renal injury. In cultured endothelial cells, ECFC-derived exosomes ameliorated endothelial cell apoptosis through caspase-3 inhibiton.

Where do EPCs come from?

There are conflicting data about the possible sources of EPCs, in several studies EPCs were found to have bone marrow (BM) origin, in other studies EPCs were shown to be tissue resident cells. In a mouse model of selective endothelial injury by Hohenstein et al. [27, 28], BM-derived cells carrying markers of EPCs were found in injured kidneys and these cells were shown to contribute to subsequent healing of endothelial lesions. However, in another study, Sradnick et al. investigated the potential role of EPCs in renal endothelial cell repair [29]. In this study, extrarenal cells were not found to replace any mature endothelial cells suggesting that endothelial repair depends on local mechanisms in acute endothelial injury model. In another words, instead of giving rise to mature EPCs inside the kidney, cell therapy with EPCs were suggested to indirectly take part in the endothelial repair process via angiogenic cytokines. Authors suggested naming these cells als "pro-angiogenic cells" instead of EPCs.

\section{Methods used in EPC studies}

EPCs can be studied by 3 strategies; 1- direct cell counting with flow cytometry, 2cultivating EPCs in fibronectin-coated plates and counting the cells growing in the culture, 3- combination of these 2 strategies, cell sorting of EPCs and then cultivation of these cells (Fig.1). 


\section{Kidney Blood Pressure Research}

Flow cytometry is advantageous because direct counting of the cells without complicated culture steps makes this approach reliable. However there is no consensus on the exact definition of EPC in terms of surface markers and it is not possible to perform functional tests in flow cytometry. These are the main limitations of the flow cytometry.

The main advantage of the culture method is that it makes the functional tests possible. Migratory activity, tube formation capability as an in vitro model for angiogenesis and adhesion capacity to endothelial cells and to extracellular matrix molecules are possible functional tests. Indeed, even if specific functional studies are not performed, culture method suggests important functional

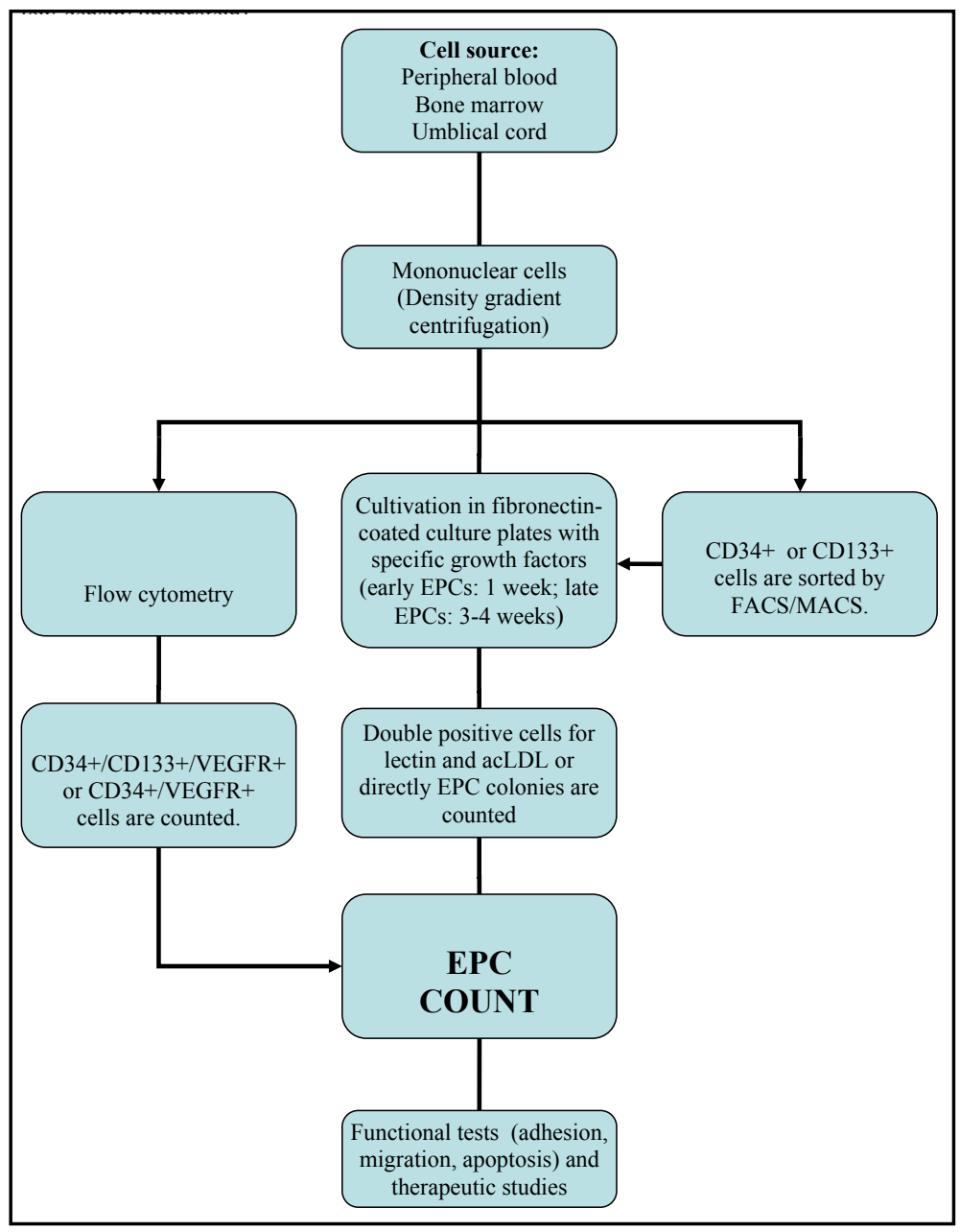

Fig. 1. Culture and flow cytometry methods for counting and cultivation of EPCs (FACS: Fluorescence-activated cell sorting, MACS: Magnetic-activated cell sorting, acLDL: acetylated low-density lipoprotein) characteristics of EPCs such as capabilities of differentiation and proliferation. However cell culture consists of complicated in vitro steps making this method vulnerable to flaws. Since, very high concentrations of growth factors are needed in culture method when compared to in vivo, cultivated EPCs may not represent the EPCs in normal physiology.

Combination of these two strategies is also possible [30-32]. EPCs may be selected by fluorescence-activated cell sorting (FACS) or magnetic-activated cell sorting (MACS) and then these cells may be cultivated. In this method, both the EPC counts and functional test may be performed.

Direct cell counting with flow cytometry is generally accepted as the method of choice for determination of EPC number [33]. However, in certain situations, EPC dysfunction rather than absolute EPC count may be more important [34]. In such cases, investigation of functional and clonogenic properties of EPCs may be required necessitating cell culture methods. Performing both the flow cytometry and cell culture methods may provide further complementary data. 


\section{Kidney Blood Pressure Research}

\section{Factors affecting EPC counts}

Factors affecting EPC counts are presented in Table 1. In summary, EPC counts and functions are negatively affected by uremia, inflammation and other risk factors for atherosclerosis such as smoking, diabetes mellitus and hypercholesterolemia [35, 36]. Acute tissue injuries, certain drugs such as statins and growth factors and erythropoietin are associated with increased EPC counts and/or functions [37-39].

\section{EPC studies in various disease models}

EPCs and cardiovascular diseases: prognostic importance of EPCs

EPC counts may be reliable markers of vascular health $[33,40]$. Decreased EPC counts may hinder re-endothelization after vascular injury leading to endothelial dysfunction, intimal hyperplasia and eventually thrombosis [41-43]. Vasculoprotective role and prognostic importance of EPCs in atherosclerotic diseases have been shown in "Endothelial Progenitor Cells in Coronary Artery Disease" study [33]. In this study, effects of CD34+/ kinase insert domain receptor (KDR)+ cell counts on cardiovascular end-points were investigated in patients with coronary artery disease (CAD). After adjusting for vascular risk factors, drug treatments and comorbidities; high EPC counts were significantly associated with lower risk of cardiovascular mortality, the need of revascularization and hospitalization. Indeed, circulating EPC counts have been shown to predict the impairment of vascular reactivity far better than Framingham risk factor scoring (40). Other studies have also shown negative correlations between EPC counts and cardiovascular risk factors and mortality [44, 45]. CD34+/KDR+ cells were found to be reduced by $50 \%$ in patients with CAD compared to healthy controls. Furthermore EPCs isolated from patients with CAD were found to have impaired migratory response [44]. In a study performed on subjects with cardiovascular

Table 1. Factors affecting EPC counts and functions. (ACE: angiotensin converting enzyme, ARB:angiotensin-2 receptor blockers, VEGF: vascular endothelial growth factor, GM-CSF: granulocyte-macrophage colony stimulating factor, SDF-1: stromal cell-derived factor-1, HGF: hepatocyte growth factor, eNOS:endothelial nitric oxide synthase, ADMA: asymmetric dimethyl-arginine)

\begin{tabular}{|c|c|}
\hline Increased EPC counts/functions & Decreased EPC counts/functions \\
\hline $\begin{array}{l}\text { Hypoxemia [124] } \\
\text { Exercise }[125]\end{array}$ & \\
\hline Heart failure (early phase) [126] & Advanced age $[142]$ \\
\hline Acute myocardial infection [127] & Chronic kidney disease $[46,49,50,56,57]$ \\
\hline Stroke $[128]$ & Diabetes mellitus [36] \\
\hline Local tissue ischemia [129] & Hypercholesterolemia [60] \\
\hline Vascular injury [130] & Heart failure (late phase) [127] \\
\hline Ischemic preconditioning [131] & Hyperhomosisteinemia [143] \\
\hline 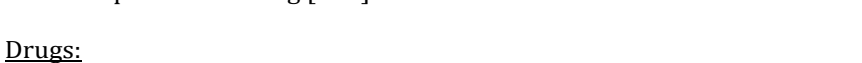 & $\begin{array}{l}\text { Increased inflammation (high CRP } \\
\text { levels) [59] }\end{array}$ \\
\hline $\begin{array}{l}\text { Statins [1,132], erythropoietin [38,39], ACE inhibitors [133], ARBs [134], } \\
\text { roziglitazone [135] Sitagliptin [136] }\end{array}$ & $\begin{array}{c}\text { Inflammatory diseases (rhematoid } \\
\text { arthritis) }[144] \\
\text { Smoking [145] }\end{array}$ \\
\hline Cytokines and growth factors: & Drugs: \\
\hline $\begin{array}{l}\text { VEGF [137], GM-CSF [130], anjiopoietin-1 [138], SDF-1 [139], HGF [140], } \\
\text { melatonin [141] }\end{array}$ & Rapamycin [146] \\
\hline Genetic modifications: & $\begin{array}{c}\text { Cytokines and growth factors: } \\
\text { Indoxyl sulphate [147] } \\
\text { P-cresol [148] }\end{array}$ \\
\hline $\begin{array}{l}\text { Overexpression of eNOS [115] } \\
\text { Overexpression of heme-oxygenase } 1[115]\end{array}$ & ADMA [149] \\
\hline Overexpression of telomerase reverse-transcriptase [116] & Genetic modifications: \\
\hline Deletion of p66ShcA [117] & Sirtuin-1 knockout [150] \\
\hline Downregulation of the Ets1 transcription factor [118] & \\
\hline
\end{tabular}




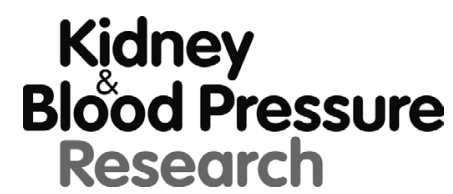

Kidney Blood Press Res 2018;43:701-718

\begin{tabular}{|l|l|}
\hline DOI: $10.1159 / 000489745$ & (c) 2018 The Author(s). Published by S. Karger AG, Basel \\
\hline
\end{tabular}

Published online: 16 May, 2018

www.karger.com/kbr

Ozkok et al.: EPCs and Kidney Diseases

risk factors but wihout a history of CVD, EPC counts were significantly associated with flow-mediated dilatation (FMD) of brachial-artery, an indicator of endothelial function [40]. However in our previous study, EPC counts were not associated with FMD or carotid intima-media thickness in HD patients [46]. We suggested that other uremia-related factors might have overriden the clinical picture concealing the possible effects of decreased EPC counts on endothelial function and atherosclerosis. Decreased EPC counts have also been found to be associated with early and frequent restenosis of dialysis vascular accesses after percutaneous angioplasty [47]. In a 3-year prospective study by Hsiesh et al. [48], decreased circulating EPC counts (defined as CD34+KDR+ cells) were significantly associated with systemic vascular thrombosis and vascular access thrombosis.

\section{EPCs and chronic kidney disease}

EPC counts have been reported to be lower in CKD patients $[49,50]$. Decreased EPC counts in CKD may be caused by impaired EPC mobilization from BM, depletion of EPCs due to increased demand or sequestration of EPCs in kidneys [51]. In our previous study, we also found that EPC counts determined by cell culture method were singificantly lower in HD patients compared to healthy controls [46].

In vitro studies showed that uremic serum caused EPC dysfunction and also impaired differentiation of mononuclear cells to EPC [52]. Indoxyl-sulfate (IS) which is a proteinbound uremic toxin, was found to have a toxic effect on vascular endothelial cells [53] and renal tubular cells $[54,55]$. In the study by Lin et al. [56], IS inhibited colony formation and functions of EPCs in a dose dependent manner in patients with CKD.

EPC counts may be inversely correlated with the degree of renal dysfunction. In the study by Surdacki et al. [57], glomerular filtration rate was inversely associated with CD34+/ $\mathrm{KDR}+$ cell counts in patients with CAD.

Inflammation is the one of the cornerstones in the pathophysiology of CKD. Uremiainduced inflammation contributes to EPC dysfunction. Proinflammatory cytokines are known to impair EPC functions and differentiation [58, 59]. In our previous study, we found that EPC counts were negatively associated with inflammation [46]. Specifically, EPC number determined by cell culture method was inversely associated with serum TNF- $\alpha$ levels in HD patients. Furthermore, CD34+/VEGFR-2+ cell counts were negatively related to serum interleukin-6 levels.

Other important factors associated with EPC dysfunction in CKD may be the oxidative stress and inadequate nitric oxide (NO) production [60-63]. Increased oxidative stress may lead to impaired differentiation of EPCs to mature endothelial cells and disordered regeneration of injured vascular endothelium $[60,61]$. NO synthase which is necessary for EPC mobilization, is inhibited by uremic guanidin compounds resulting in inadequate NO production that leads to impaired mobilization of EPC from BM [64].

While CKD is affecting EPC counts and functions, EPCs may also have influence on the progression of CKD. Possible effect of EPC treatment on the progression of CKD was investigated in a 5/6 nephrectomy model [65]. In this study, adoptively transferred EPCs homed to the injured kidney, decreased inflammation and proteinuria and consequently renal structures and functions were preserved.

\section{Influence of dialysis dose and modalities on EPCS}

Dialysis dose is an index of clearance of uremic toxins and it is significantly associated with the prognosis of patients with CKD $[66,67]$. HD dose was also found to be associated with EPC functions; higher HD dose was related to recovery of angiogenic functions of EPCs [49]. However thrice weekly HD may not be adequate for the recovery of EPC health. Increasing dialysis dose may be associated with better outcomes. EPC counts and migratory functions of patients under nocturnal HD treatment were comparable with those of healthy controls [68]. Similarly, EPC counts were reported to be normalized in patients treated with high-efficiency peritoneal dialysis modalities [69]. In the study by Yuen et al. [70], early EPCs 


\section{Kidney Blood Pressure Research}

Kidney Blood Press Res 2018;43:701-718

\begin{tabular}{l|l}
\hline DOI: $10.1159 / 000489745$ & (C) 2018 The Author(s). Published by S. Karger AG, Basel
\end{tabular}

Published online: 16 May, 2018

www.karger.com/kbr

Ozkok et al.: EPCs and Kidney Diseases

were cultured from healthy controls, conventional and nocturnal HD patients and these EPCs were administered into the ischemic hindlimb of rats 1 day after left common iliac artery ligation. EPCs obtained from conventional HD had no effect on ischemia however EPCs from nocturnal HD and healthy controls significantly improved ischemic hindlimb perfusion and capillary density.

Besides the dose of the dialysis, different dialysis modalities may have influence on EPC counts or functions. High-flux HD with online hemodiafiltration (HDF) is well-known to be associated with better middle molecule removal and reduced inflammation [71]. In a crossover trial by Krieter et al. [72], 18 patients were subjected to 4 weeks of low-flux HD, highflux HD and HDF. However, in this study, dialysis modalities had no effect on EPC numbers.

\section{EPCs in ischemic AKI models}

In an animal model of renal ischemia/reperfusion (I/R) injury, Pang et al. investigated renal artery-derived progenitor cells (RAPC) (defined as CD34+/CD105-cells) obtained from human renal arterial adventitia of radical nephrectomy specimens [73]. RAPC were found to have EPC-like characteristics. Injected RAPC integrated into endothelium after acute ischemia/reperfusion (I/R) injury and decreased serum creatinine levels and albuminuria and improved blood flow. Endothelial migration was improved when injured endothelial cells were exposed to RAPC-derived exosomes containing high levels of miRNA-218.

EPCs may also affect the recovery process of AKI and may reduce the progression to CKD after AKI. In an ischemic AKI model by Pastchan et al. [74], systemic injection of early EPCs decreased serum creatinine and ameliorated interstitial fibrosis. Exposure of endothelial cells to early EPC supernatant led to decreased smooth muscle actin and tubulin expression. Furthermore percentages of cilium-positive cells were increased resulting in reduced endothelial-to-mesenchymal transformation. In this study, authors concluded that endothelial cilia might be suggested as an anti-fibrotic organelle and early EPCs might stabilize cilia integrity and functions in ischemic AKI.

\section{EPCs in sepsis}

Sepsis seems to increase the number of circulating EPCs but impair their functions [7577]. In the study by Becchi et al. [75], EPC numbers were increased in sepsis and furthermore, EPC counts were associated with the severity of the sepsis. Similarly Rafat et al. [76] found that increased EPC counts were associated with the survival of patients with sepsis. In the study by Patschan et al. [77], EPC counts (defined as CD133+/Flk-1+) were also found to be increased in sepsis however patients with increased creatinine levels showed even higher EPC counts. EPC proliferation was investigated by a colony-forming units assay and sepsis was found to significantly impair the proliferative capacity of EPCs. In this study, serum levels of stromal cell-derived factor-1, angiopoietin-2, and VEGF were significantly increased in patients with sepsis. These molecules are known to enhance the mobilization of EPCs suggesting an explanation for increased EPC counts in sepsis [78].

\section{EPCs in glomerulonephritis models}

EPCs were also studied in glomerulonephritis models and administration of EPCs was found to have favorable effects on disease processes. In the study by Uchimura et al. [79], possible effects of bone-marrow derived mononuclear cells on glomerular endothelial cell injury were investigated in an anti-Thy-1.1 nephritis model. These cells were enriched in a BM culture after cultivation under conditions that promote EPC and administered only to the left kidney via renal artery. These cells integrated into the glomerular endothelium and took role in the repair processes. Compared to contralateral kidney, endothelial injury was lower in the cell-transferred kidney. Similarly, other several studies with glomerulonephritis models, have shown that BM derived cells were recruited into the kidney and repaired the endothelium leading to decreased endothelial injury [80, 81]. In a study performed on a model of IgA nephropathy [82], EPC administration to rats resulted in decreased proteinuria 


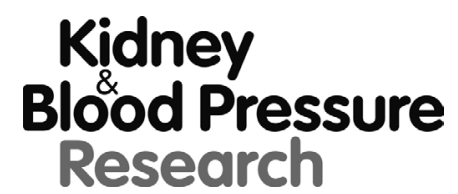

Kidney Blood Press Res 2018;43:701-718

\begin{tabular}{|l|l|}
\hline DOI: $10.1159 / 000489745$ & (c) 2018 The Author(s). Published by S. Karger AG, Basel \\
\hline
\end{tabular}

Published online: 16 May, 2018

www.karger.com/kb

Ozkok et al.: EPCs and Kidney Diseases

and serum creatinine levels. Furthermore, EPC transplantation diminished glomerular extracellular matrix and IgA deposition in the glomeruli slowing the progression of IgA nephropathy.

\section{EPCs in renal artery stenosis models}

EPC treatments have been shown to be beneficial in renal artery stenosis (RAS) models. In the study by Chade et al. [83], EPC injection into the stenotic kidney improved microvascular density, renal functions and diminished fibrosis in an experimental RAS model. In another study by Ebrahimi et al. [84], EPC administration resulted in EPC engraftment into the tubular structures leading to improved tubular functions and decreased fibrosis in a swine RAS model.

\section{EPCs in renal transplantation}

RT has been shown to improve vascular functions and decrease cardiovascular mortality compared to chronic HD [85-87]. However, there are controversial results about the role and functions of EPCs in RT. In the study by Soler et al. [88], EPC counts and proliferation capacities were found to be decreased in RT recipients compared to healthy controls. Herbrig et al. [89] showed that EPC counts were decreased however EPC functions were improved after RT. Decreased EPC counts in this study could be explained by two reasons: 1erythropoiesis stimulating agents which are powerful EPC stimulators are usually withdrawn in post-transplant period, 2- immunosuppresive treatments especially cyclosporine and corticosteroids might have impaired the differention of EPCs from mononuclear cells. In the study by De Groot et al. [90], EPC counts in RT recipients were similar to healthy controls but significantly higher than uremic patients. In this study, EPC numbers were correlated significantly with the graft function in RT recipients. In the study by Di Marco et al. [91], RT patients were compared to healthy controls in terms of EPC numbers (defined as CD133+/ VEGFR2+ and CD34+/VEGFR2+). EPC counts were higher in RT recipients compared to controls. Furthermore in a 5/6 nephrectomy model, possible impact of immunosuppressive drugs on EPC counts was investigated. EPC counts were lower in rats with CKD compared to control animals however administration of immunosuppressives restored the EPC counts in these rats. Authors suggested that these drugs might contribute to increased EPC counts observed in RT patients.

EPCs may also play important roles in the acute and chronic rejection processes in RT patients. In several studies, EPCs were shown to accumulate in renal allograft in cases of rejection as a response to increased expression of adhesion molecules, chemokines and growth factors such as VEGF $[92,93]$. Consequently an increased angiogenesis is observed in such situations. In acute diseases such as ischemic nephropathy and in chronic states such as tubulointerstitial fibrosis and aging, microvascular rarefaction is the main pathology in which increased angiogenesis by the way of EPCs may be beneficial [94-97]. However in cases of chronic allograft vasculopathy (CAV), persistent injury leads to accumulation of leukocytes and EPCs that result in a reciprocal process of inflammation and angiogenesis. In such cases, angiogenesis itself increases inflammation and vice versa [98-100]. Thus inhibition of angiogenesis may attenuate the development of CAV [101]. Although chimerism created by the homing of EPCs to allograft's endothelium may be beneficial in acute insults, it may increase indirect pathway of allorecognition leading to immunologic injury in chronic rejection $[102,103]$. In the study by Yang et al. [104] performed on an abdominal aortic transplant model, injected EPCs (defined as stem cell antigen-1+/ Flk-1+ cells) did not promote re-endothelialization after transplantation, but rather increased endothelial cell damage, leading to transplant arteriosclerosis in the allograft transplantation group. Furthermore, vandetanib- a tyrosine kinase inhibitor acting as a VEGFR inhibitor- was found to reduce transplant arteriosclerosis by inhibiting proliferation, migration and adhesion of EPCs. 


\section{Kidney Blood Pressure Research}

Ozkok et al.: EPCs and Kidney Diseases

\section{Possible adverse effects of EPCs: “Bad" EPCs?}

Although EPCs are known to have favorable effects on vascular health, a subset of EPCs may be associated with atherosclerotic plaque instability by the way of increased neovascularization leading to the progression of atherosclerosis [105-109]. In the study by Flammer et al. [110], circulating osteocalcin+ early EPCs were strongly associated with unstable coronary artery disease. Authors suggested that this particular EPC subset might cause abnormal vascular repair.

CD133+ cells belong to a subset of undifferentiated stem cells with controversial role in the pathogenesis of CVD [111]. There are several studies about the role of CD133+ cells in prevention of various CVD with favorable results $[112,113]$. However, in other studies, these cells had detrimental effects on cardiovascular health [105-109, 114]. For example intracoronary injection of CD133+ cells was found to increase in-stent restenosis [108]. In another study, CD133+ cell injection increased inflammation and ischemic AKI in a mice model [105]. Neutrophil infiltration and myeloperoxidase activity increased in kidneys and TNF- $\alpha$ levels increased in plasma. In this study, increased TNF- $\alpha$ was suggested to be responsible for the pro-inflammatory effects of CD133+ cells [105]. In parallel to this study, in our previous study performed on HD patients, we found that CD133+ cell counts were associated with increased inflammation determined by serum TNF- $\alpha$ and resistin concentrations [114]. Importantly, in our study, CD133+ cell counts were significantly negatively related to FMD suggesting possible adverse effects of these cell types on endothelial functions.

\section{EPC engineering: Improving EPC functions and delivery}

Certain cellular modifications may enhance EPC functions. For example, overexpression of eNOS or heme-oxygenase-1 resulted in improvement of EPC functions [115]. Overexpression of telomerase reverse-transcriptase in EPCs improved neovascularization of ischemic limbs [116]. p66ShcA deletion was shown to reduce glucose-induced oxidative stress and improve the viability of EPCs [117]. In another study, downregulation of the Ets1 transcription factor increased EPC numbers and differentiation to endothelial cells in a mouse model of metabolic syndrome and type-2 diabetes mellitus [118].

Delivery of EPCs to the desired site of injury is an important issue in therapeutic use of EPCs. There may be some problems in the administration of EPCs: 1 ) only a small percentage of EPC may be able to home to the kidney $[119,120] ; 2)$ inadequate cellular integrin activation may lead to apoptosis of EPCs if the cells are administered in an aqueous solution [121]. To prevent these possible problems, Ratliff et al. [122] administered EPCs within hyaluronic acid-based hydrogels into the ears or injected EPCs subcapsularly into the kidneys. Postischemic kidney functions were significantly improved in both types of administration. This approach of delivery of EPCs within hydrogels was found to be superior to intravenous EPC injection.

Decellularized organ scaffolds have been increasingly used in regenerative medicine. In the study by Wang et al. [123], partial nephrectomy was performed and these kidneys were repaired with decellularized renal scaffolds in rats. Subsequently, EPCs were injected into the rats.With this approach, angiogenesis and microvascular density were found to be higher compared to control group. Decellularized renal scaffolds may provide a convenient microenvironment for EPCs in the repair process after kidney injury. 


\section{Kidney Blood Pressure Research}

Ozkok et al.: EPCs and Kidney Diseases

\section{Future of EPC studies}

Since the most important problem in EPC research is the lack of a common EPC definition, further studies should focus on the definition of EPCs. EPCs have been clearly shown to be important predictors in CVD but not in kidney diseases. Possible prognostic aspects of EPC counts and functions should be investigated especially in AKI and RT. Therapeutic roles of EPCs have been studied in various kidney diseases with mostly cell culture and animal models. Further human trials should be performed possibly by engineered EPCs with greater therapeutic benefits. However, possible advers effects of certain subsets of EPCs such as endothelial dysfunction and increased cardiovascular risks should be kept in mind in human studies.

\section{Conclusion}

EPCs are shown to have important roles in the the maintenance of vascular integrity and repairment of endothelial damage. Although EPCs may be capable of engrafting and regenerating endothelium, the most important effects of EPCs seem to be depended on paracrine effects. EPC counts have strong prognostic implications in CVD. Importantly, EPCs, as therapeutic agents, have been found to be beneficial for especially AKI. Further human studies investigating EPC therapies for kidney diseases are needed.

\section{Disclosure Statement} article.

The authors declare they have no conflicts of interests regarding the publication of this

\section{References}

1 Walter DH, Rittig K, Bahlmann FH, Kirchmair R, Silver M, Murayama T, Nishimura H, Losordo DW, Asahara T, Isner JM: Statin therapy accelerates reendothelialization: a novel effect involving mobilization and incorporation of bone marrow-derived endothelial progenitor cells. Circulation 2002;105:3017-3024.

2 Rafii S, Lyden D: Therapeutic stem and progenitor cell transplantation for organ vascularization and regeneration. Nat Med 2003;9:702-712.

- Foley RN, Parfrey PS, Sarnak MJ: Clinical epidemiology of cardiovascular disease in chronic renal disease. Am J Kidney Dis. 1998;32:S112-S119.

$\checkmark 4$ Goldsmith DJ, Covic A: Coronary artery disease in uremia: Etiology, diagnosis, and therapy. Kidney Int 2001;60:2059-2078.

-5 Ishimura E, Shoji T, Emoto M, Motoyama K, Shinohara K, Matsumoto N, Taniwaki H, Inaba M, Nishizawa Y: Renal insufficiency accelerates atherosclerosis in patients with type 2 diabetes mellitus. Am J Kidney Dis 2001;38:S186-S190.

-6 Cheung AK, Sarnak MJ, Yan G, Dwyer JT, Heyka RJ, Rocco MV, Teehan BP, Levey AS: Atherosclerotic cardiovascular disease risks in chronic hemodialysis patients. Kidney Int 2000;58:353-362.

-7 Asahara T, Murohara T, Sullivan A, Silver M, van der ZR, Li T, Witzenbichler B, Schatteman G, Isner JM: Isolation of putative progenitor endothelial cells for angiogenesis. Science 1997;275:964-967.

8 Urbich C, Dimmeler S: Endothelial progenitor cells functional characterization. Trends Cardiovasc Med 2004;14:318-322.

-9 Bahlmann FH, Speer T, Fliser D: Endothelial progenitor cells in chronic kidney disease. Nephrol Dial Transplant 2010;25:341-346. 


\section{Kidney \\ Blood Pressure Research}

10 Hristov M, Weber C: Endothelial progenitor cells: characterization, pathophysiology, and possible clinical relevance. J Cell Mol Med 2004;8:498-508.

11 Goligorsky MS, Yasuda K, Ratliff B: Dysfunctional endothelial progenitor cells in chronic kidney disease. J Am Soc Nephrol 2010;21:911-919.

-12 Fadini GP, Losordo D, Dimmeler S: Critical reevaluation of endothelial progenitor cell phenotypes for therapeutic and diagnostic use. Circ Res 2012;110:624-637.

13 Cantaluppi V, Gatti S, Medica D, Figliolini F, Bruno S, Deregibus MC, Sordi A, Biancone L, Tetta C, Camussi G: Microvesicles derived from endothelial progenitor cells protect the kidney from ischemia reperfusion injury by microRNA-dependent reprogramming of resident renal cells. Kidney Int 2012;82: 412-427.

14 Yasuda K, Khandare A, Burianovskyy L, Maruyama S, Zhang F, Nasjletti A, Goligorsky MS: Tunneling nanotubes mediate rescue of prematurely senescent endothelial cells by endothelial progenitors: exchange of lysosomal pool. Aging 2011;3:597-608.

15 Patschan D, Schwarze K, Henze E, Patschan S, Müller GA: Endothelial autophagy and endothelial-tomesenchymal transition (EndoMT) in eEPC treatment of ischemic AKI. J Nephrol 2016;29:637-644.

16 Lapergue B, Mohammad A, Shuaib A: Endothelial progenitor cells and cerebrovascular diseases. Prog Neurobiol 2007;83:349-362.

17 Povsic T, Goldschmidt-Clermont P: Endothelial progenitor cells: Markers of vascular reparative capacity. Therapeutic Adv Cardiovasc Dis 2008;2:199-213.

18 Ingram DA, Caplice NM, Yoder MC: Unresolved questions, changing definitions, and novel paradigms for defining endothelial progenitor cells. Blood 2005;106:1525-1531.

19 Patschan D, Kribben A, Müller GA: Postischemic microvasculopathy and endothelial progenitor cell-based therapy in ischemic AKI: update and perspectives. Am J Physiol Renal Physiol 2016;1;311:F382-394.

20 Patschan D, Schwarze K, Tampe B, Zeisberg M, Patschan S, Müller GA: Endothelial colony forming cells (ECFCs) in murine AKI - implications for future cell-based therapies. BMC Nephrol 2017;6;18:53.

-21 Lee Y, El Andaloussi S, Wood MJ: Exosomes and microvesicles: extracellular vesicles for genetic information transfer and gene therapy. Hum Mol Genet 2012;21:R125-R134.

-22 Livingston MJ, Wei Q: MicroRNAs in extracellular vesicles protect kidney from ischemic injury: from endothelial to tubular epithelial. Kidney Int 2016;90:1150-1152.

23 Deregibus MC, Cantaluppi V, Calogero R, Lo Iacono M, Tetta C, Biancone L, Bruno S, Bussolati B, Camussi G: Endothelial progenitor cell derived microvesicles activate an angiogenic program in endothelial cells by a horizontal transfer of mRNA. Blood 2007;110:2440-2448.

24 Cantaluppi V, Medica D, Mannari C, Stiaccini G, Figliolini F, Dellepiane S, Quercia AD, Migliori M, Panichi V, Giovannini L, Bruno S, Tetta C, Biancone L, Camussi G: Endothelial progenitor cell-derived extracellular vesicles protect from complement-mediated mesangial injury in experimental anti-Thy1.1 glomerulonephritis. Nephrol Dial Transplant 2015;30:410-422.

25 Viñas JL, Burger D, Zimpelmann J, Haneef R, Knoll W, Campbell P, Gutsol A, Carter A, Allan DS, Burns KD: Transfer of microRNA-486-5p from human endothelial colony forming cell-derived exosomes reduces ischemic kidney injury. Kidney Int 2016;90:1238-1250.

-26 Burger D, Viñas JL, Akbari S, Dehak H, Knoll W, Gutsol A, Carter A, Touyz RM, Allan DS, Burns KD: Human endothelial colony-forming cells protect against acute kidney injury: role of exosomes. Am J Pathol 2015;185:2309-2323.

-27 Hohenstein B, Kuo MC, Addabbo F, Yasuda K, Ratliff B, Schwarzenberger C, Eckardt KU, Hugo CP, Goligorsky MS: Enhanced progenitor cell recruitment and endothelial repair after selective endothelial injury of the mouse kidney. Am J Physiol Renal Physiol 2010;298:F1504-F1514.

28 Hohenstein B, Braun A, Amann KU, Johnson RJ, Hugo CP: A murine model of site-specific renal microvascular endothelial injury and thrombotic microangiopathy. Nephrol Dial Transplant 2008;23:11441156.

29 Sradnick J, Rong S, Luedemann A, Parmentier SP, Bartaun C, Todorov VT, Gueler F, Hugo CP, Hohenstein B: Extrarenal progenitor cells do not contribute to renal endothelial repair. J Am Soc Nephrol 2016;27:17141726.

30 Gehling UM, Ergün S, Schumacher U, Wagener C, Pantel K, Otte M, Schuch G, Schafhausen P, Mende T, Kilic N, Kluge K, Schäfer B, Hossfeld DK, Fiedler W: In vitro differentiation of endothelial cells from AC133-positive progenitor cells. Blood 2000;15;95:3106-3112. 


\section{Kidney \\ Blood Pressure Research}

31 Peichev M, Naiyer AJ, Pereira D, Zhu Z, Lane WJ, Williams M, Oz MC, Hicklin DJ, Witte L, Moore MA, Rafii S: Expression of VEGFR-2 and AC133 by circulating human CD34(+) cells identifies a population of functional endothelial precursors. Blood 2000;1;95:952-958.

-32 de Wynter EA, Buck D, Hart C, Heywood R, Coutinho LH, Clayton A, Rafferty JA, Burt D, Guenechea G, Bueren JA, Gagen D, Fairbairn LJ, Lord BI, Testa NG: CD34+AC133+ cells isolated from cord blood are highly enriched in long-term culture-initiating cells, NOD/SCID-repopulating cells and dendritic cell progenitors. Stem Cells 1998;16:387-396.

-33 Werner N, Kosiol S, Schiegl T, Ahlers P, Walenta K, Link A, Böhm M, Nickenig G: Circulating endothelial progenitor cells and cardiovascular outcomes. N Engl J Med 2005;353:999-1007.

-34 Heeschen C, Lechmann R, Honold J, Assmus B, Aicher A, Walter DH, Martin H, Zeiher AM, Dimmeler S: Profoundly reduced neovascularization capacity of bone marrow mononuclear cells derived from patients with chronic ischemic heart disease. Circulation 2004;109:1615-1622.

-35 Heiss C, Keymel S, Niesler U, Ziemann J, Kelm M, Kalka C: Impaired progenitor cell activity in age-related endothelial dysfunction. J Am Coll Cardiol 2005;45:1441-1448.

-36 Tepper OM, Galiano RD, Capla JM, Kalka C, Gagne PJ, Jacobowitz GR, Levine JP, Gurtner GC: Human endothelial progenitor cells from type II diabetics exhibit impaired proliferation, adhesion, and incorporation into vascular structures. Circulation 2002;106:2781-2786.

37 Heeschen C, Aicher A, Lehmann R, Fichtlscherer S, Vasa M, Urbich C, Mildner-Rihm C, Martin H, Zeiher AM, Dimmeler S: Erythropoietin is a potent physiological stimulus for endothelial progenitor cell mobilization. Blood 2003;102:1340-1346.

-38 Bahlmann FH, DeGroot K, Duckert T, Niemczyk E, Bahlmann E, Boehm SM, Haller H, Fliser D: Endothelial progenitor cell proliferation and differentiation is regulated by erythropoietin. Kidney Int 2003;64:16481652.

39 Bahlmann FH, deGroot K, Spandau JM, Landry AL, Hertel B, Duckert T, Boehm SM, Menne J, Haller H, Fliser D: Erythropoietin regulates endothelial progenitor cells. Blood 2004;103:921-926.

-40 Hill JM, Zalos G, Halcox JPJ, Schenke WH, Waclawiw MA, Quyyumi AA, Finkel T: Circulating endothelial progenitor cells, vascular function, and cardiovascular risk. N Engl J Med 2003;348:593-600.

41 Pelliccia F, Cianfrocca C, Rosano G, Mercuro G, Speciale G, Pasceri V: Role of endothelial progenitor cells in restenosis and progression of coronary atherosclerosis after percutaneous coronary intervention: a prospective study. J Am Coll Cardiol Intv 2010;3:78-86.

-42 Huang PH, Chen YH, Chen YL, Wu TC, Chen JW, Lin SJ: Vascular endothelial function and circulating endothelial progenitor cells in patients with cardiac syndrome X. Heart 2007;93:1064-1070.

43 Padfield GJ, Newby DE, Mills NL: Understanding the role of endothelial progenitor cells in percutaneous coronary intervention. J Am Coll Cardiol 2010;55:1553-1565.

44 Vasa M, Fichtlscherer S, Aicher A, Adler K, Urbich C, Martin H, Zeiher AM, Dimmeler S. Number and migratory activity of circulating endothelial progenitor cells inversely correlate with risk factors for coronary artery disease. Circ Res 2001;89:E1-7.

45 Werner L, Deutsch V, Barshack I, Miller H, Keren G, George J: Transfer of endothelial progenitor cells improves myocardial performance in rats with dilated cardiomyopathy induced following experimental myocarditis. J Mol Cell Cardiol 2005;39,691-697.

\$6 Ozkok A, Aktas E, Yilmaz A, Telci A, Oflaz H, Deniz G, Yildiz A: Decrease in endothelial progenitor cells associated with inflammation, but not with endothelial dysfunction in chronic hemodialysis patients. Clin Nephrol 2013;79:21-30.

47 Wu CC, Huang PH, Lai CL, Leu HB, Chen JW, Lin SJ: The impact of endothelial progenitor cells on restenosis after percutaneous angioplasty of hemodialysis vascular access. PLoS One 2014;9:e101058.

48 Hsieh MY, Chen TY, Lin L, Chuang SY, Lin SJ, Tarng DC, Huang PH, Wu CC: Deficiency of circulating progenitor cells associated with vascular thrombosis of hemodialysis patients. Nephrol Dial Transplant 2017;32:556-564.

49 Choi JH, Kim KL, Huh W, Kim B, Byun J, Suh W, Sung J, Jeon ES, Oh HY, Kim DK: Decreased number and impaired angiogenic function of endothelial progenitor cells in patients with chronic renal failure. Arterioscler Thromb Vasc Biol 2004;24:1246-1252.

50 de Groot K, Bahlmann FH, Sowa J, Koenig J, Menne J, Haller H, Fliser D: Uremia causes endothelial progenitor cell deficiency.Kidney Int 2004;66:641-646. 


\section{Kidney \\ Blood Pressure Research}

51 Hickson LJ, Eirin A, Lerman LO: Challenges and opportunities for stem cell therapy in patients with chronic kidney disease. Kidney Int 2016;89:767-778.

-52 Herbrig K, Pistrosch F, Oelschlaegel U, Wichmann G, Wagner A, Foerster S, Richter S, Gross P, Passauer J: Increased total number but impaired migratory activity and adhesion of endothelial progenitor cells in patients on long-term hemodialysis. Am J Kidney Dis 2004;44:840-849.

53 Dou L, Bertrand E, Cerini C, Faure V, Sampol J, Vanholder R, Berland Y, Brunet P: The uremic solutes p-cresol and indoxyl sulfate inhibit endothelial proliferation and wound repair. Kidney Int 2004;65:442-451.

54 Motojima M, Hosokawa A, Yamato H, Muraki T, Yoshioka T: Uremic toxins of organic anions up-regulate PAI1 expression by induction of NF-KB and free radical in proximal tubular cells. Kidney Int 2003;63:16711680.

55 Shimizu H, Bolati D, Adijiang A, Muteliefu G, Enomoto A, Nishijima F, Dateki M, Niwa T: NF-кb plays an important role in indoxyl sulfate-induced cellular senescence, fibrotic gene expression, and inhibition of proliferation in proximal tubular cells. Am J Physiol Cell Physiol 2011;301:C1201-C1212.

-56 Lin CJ, Wu CJ, Wu PC, Pan CF, Wang TJ, Sun FJ, Liu HL, Chen HH, Yeh HI: Indoxyl sulfate impairs endothelial progenitor cells and might contribute to vascular dysfunction in patients with chronic kidney disease. Kidney Blood Press Res 2016;41:1025-1036.

57 Surdacki A, Marewicz E, Wieteska E, Szastak G, Rakowski T, Wieczorek-Surdacka E, Dudek D, Pryjma J, Dubiel JS: Association between endothelial progenitor cell depletion in blood and mild-to-moderate renal insufficiency in stable angina. Nephrol Dial Transplant 2008;23:2265-2273.

58 Verma S, Kuliszewski MA, Li SH, Szmitko PE, Zucco L, Wang CH, Badiwala MV, Mickle DA, Weisel RD, Fedak PW, Stewart DJ, Kutryk MJ: C-reactive protein attenuates endothelial progenitor cell survival, differentiation, and function: further evidence of a mechanistic link between C-reactive protein and cardiovascular disease. Circulation 2004;109:2058-2067.

59 Suh W, Kim KL, Choi JH, Lee YS, Lee JY, Kim JM, Jang HS, Shin IS, Lee JS, Byun J, Jeon ES, Kim DK: C-reactive protein impairs angiogenic functions and decreases the secretion of arteriogenic chemocytokines in human endothelial progenitor cells. Biochem Biophys Res Commun 2004;321:65-71.

60 Imanishi T, Hano T, Matsuo Y, Nishio I: Oxidized low-density lipoprotein inhibits vascular endothelial growth factor-induced endothelial progenitor cell differentiation. Clin Exp Pharmacol Physiol 2003;30:665-670.

61 Boaz M, Matas Z, Biro A, Katzir Z, Green M, Fainaru M, Smetana S: Serum malondialdehyde and prevalent cardiovascular disease in hemodialysis. Kidney Int 1999;56:1078-1083.

62 MacAllister RJ, Whitley GS, Vallance P: Effects of guanidino and uremic compounds on nitric oxide pathways. Kidney Int 1994;45:737-742.

63 Aicher A, Heeschen C, Mildner-Rihm C, Urbich C, Ihling C, Technau-Ihling K, Zeiher AM, Dimmeler S: Essential role of endothelial nitric oxide synthase for mobilization of stem and progenitor cells. Nat Med 2003;9:1370-1376.

64 Jankowski J, van der Giet M, Jankowski V, Schmidt S, Hemeier M, Mahn B, Giebing G, Tolle M, Luftmann H, Schluter H, Zidek W, Tepel M: Increased plasma phenylacetic acid in patients with end-stage renal failure inhibits iNOS expression. J Clin Invest 2003;112:256-264.

65 Sangidorj O, Yang SH, Jang HR, Lee JP, Cha RH, Kim SM, Lim CS, Kim YS: Bone marrow-derived endothelial progenitor cells confer renal protection in a murine chronic renal failure model. Am J Physiol Renal Physiol 2010;299:F325-335.

66 Eknoyan G: On the epidemic of cardiovascular disease in patients with chronic renal disease and progressive renal failure: a first step to improve the outcomes. Am J Kidney Dis 1998;32:S1-S4.

67 Held PJ, Port FK, Wolfe RA, Stannard DC, Carroll CE, Daugirdas JT, Bloembergen WE, Greer JW, Hakim RM: The dose of hemodialysis and patient mortality. Kidney Int 1996;50:550-556.

-68 Chan CT, Li SH, Verma S: Nocturnal hemodialysis is associated with restoration of impaired endothelial progenitor cell biology in end-stage renal disease. Am J Physiol Renal Physiol 2005;289:F679-F684.

69 Steiner S, Schaller G, Puttinger H, Födinger M, Kopp CW, Seidinger D, Grisar J, Hörl WH, Minar E, Vychytil A, Wolzt M, Sunder-Plassmann G: History of cardiovascular disease is associated with endothelial progenitor cells in peritoneal dialysis patients. Am J Kidney Dis 2005;46:520-528. 


\section{Kidney \\ Blood Pressure Research}

70 Yuen DA, Kuliszewski MA, Liao C, Rudenko D, Leong-Poi H, Chan CT: Nocturnal hemodialysis is associated with restoration of early-outgrowth endothelial progenitor-like cell function. Clin J Am Soc Nephrol 2011;6:1345-1353.

71 Ramirez R, Carracedo J, Merino A, Nogueras S, Alvarez-Lara MA, Rodríguez M, Martin-Malo A, Tetta C, Aljama P: Microinflammation induces endothelial damage in hemodialysis patients: the role of convective transport. Kidney Int 2007;72:1008-1013.

-72 Krieter DH, Fischer R, Merget K, Lemke HD, Morgenroth A, Canaud B, Wanner C: Endothelial progenitor cells in patients on extracorporeal maintenance dialysis therapy. Nephrol Dial Transplant 2010;25:40234031.

-73 Pang P, Abbott M, Chang SL, Abdi M, Chauhan N, Mistri M, Ghofrani J, Fucci QA, Walker C, Leonardi C, Grady S, Halim A, Hoffman R, Lu T, Cao H, Tullius SG, Malek S, Kumar S, Steele G, Kibel A, et al.: Human vascular progenitor cells derived from renal arteries are endothelial-like and assist in the repair of injured renal capillary networks. Kidney Int 2017;91:129-143.

74 Patschan D, Schwarze K, Henze E, Patschan S, Müller GA: The endothelial-to-mesenchymal transition and endothelial cilia in EPC-mediated postischemic kidney protection. Am J Physiol Renal Physiol 2016;1;310:F679-F687.

75 Becchi C, Pillozzi S, Fabbri LP, Al Malyan M, Cacciapuoti C, Della Bella C, Nucera M, Masselli M, Boncinelli S, Arcangeli A, Amedei A: The increase of endothelial progenitor cells in the peripheral blood: a new parameter for detecting onset and severity of sepsis. Int J Immunopathol Pharmacol 2008;21:697-705.

76 Rafat N, Hanusch C, Brinkkoetter PT, Schulte J, Brade J, Zijlstra JG, van der Woude FJ, van Ackern K, Yard BA, Beck GCh: Increased circulating endothelial progenitor cells in septic patients: correlation with survival. Crit Care Med 2007;35:1677-1684.

77 Patschan SA, Patschan D, Temme J, Korsten P, Wessels JT, Koziolek M, Henze E, Müller GA: Endothelial progenitor cells (EPC) in sepsis with acute renal dysfunction (ARD). Crit Care 2011;15:R94.

-78 Urbich C, Dimmeler S: Endothelial progenitor cells: characterization and role in vascular biology. Circ Res 2004;95:343-353.

79 Uchimura H, Marumo T, Takase O, Kawachi H, Shimizu F, Hayashi M, Saruta T, Hishikawa K, Fujita T: Intrarenal injection of bone marrow-derived angiogenic cells reduces endothelial injury and mesangial cell activation in experimental glomerulonephritis. J Am Soc Nephrol 2005;16:997-1004.

80 Ikarashi K, Li B, Suwa M, Kawamura K, Morioka T, Yao J, Khan F, Uchiyama M, Oite T: Bone marrow cells contribute to regeneration of damaged glomerular endothelial cells. Kidney Int 2005;67:1925-1933.

81 Rookmaaker MB, Smits AM, Tolboom H, Van't Wout K, Martens AC, Goldschmeding R, Joles JA, Van Zonneveld AJ, Gröne HJ, Rabelink TJ, Verhaar MC: Bone-marrow derived cells contribute to glomerular endothelial repair in experimental glomerulonephritis. Am J Pathol 2003;163:553-562.

82 Guo W, Feng JM, Yao L, Sun L, Zhu GQ: Transplantation of endothelial progenitor cells in treating rats with IgA nephropathy. BMC Nephrol 2014;9;15:110.

83 Chade AR, Zhu XY, Krier JD, Jordan KL, Textor SC, Grande JP, Lerman A, Lerman LO: Endothelial progenitor cells homing and renal repair in experimental renovascular disease. Stem Cells 2010;28:1039-1047.

84 Ebrahimi B, Li Z, Eirin A, Zhu XY, Textor SC, Lerman LO: Addition of endothelial progenitor cells to renal revascularization restores medullary tubular oxygen consumption in swine renal artery stenosis. Am J Physiol Renal Physiol 2012;1;302:F1478-1485.

-85 Wolfe RA, Ashby VB, Milford EL, Ojo AO, Ettenger RE, Agodoa LY, Held PJ, Port FK: Comparison of mortality in all patients on dialysis, patients on dialysis awaiting transplantation, and recipients of a first cadaveric transplant. N Engl J Med 1999;341:1725-1730.

-86 Passauer J, Bussemaker E, Lassig G, Gross P: Kidney transplantation improves endothelium-dependent vasodilation in patients with end stage renal disease. Transplantation 2003;15:1907-1910.

87 Covic A, Goldsmith DJ, Gusbeth-Tatomir P, Buhaescu I, Covic M: Successful renal transplantation decreases aortic stiffness and increases vascular reactivity in dialysis patients. Transplantation 2003;76:1573-1577.

-88 Soler MJ, Martinez-Estrada OM, Puig-Mari JM, Marco-Feliu D, Oliveras A, Vila J, Mir M, Orfila A, Vilaró S, Lloveras J: Circulating endothelial progenitor cells after kidney transplantation. Am J Transplant 2005;5:2154-2159. 


\section{Kidney \\ Blood Pressure Research}

-89 Herbrig K, Gebler K, Oelschlaegel U, Pistrosch F, Foerster S, Wagner A, Gross P, Passauer J: Kidney transplantation substantially improves endothelial progenitor cell dysfunction in patients with end-stage renal disease. Am J Transplant 2006;6:2922-2928.

-90 de Groot K, Bahlmann FH, Bahlmann E, Menne J, Haller H, Fliser D: Kidney graft function determines endothelial progenitor cell number in renal transplant recipients. Transplantation 2005;79:941-945.

-91 Di Marco GS, Rustemeyer P, Brand M, Koch R, Kentrup D, Grabner A, Greve B, Wittkowski W, Pavenstädt H, Hausberg M, Reuter S, Lang D: Circulating Endothelial Progenitor Cells in Kidney Transplant Patients. PLoS ONE 2011;6:e24046.

\$2 Lagaaij EL, Cramer-Knijnenburg GF, van Kemenade FJ, van Es LA, Bruijn JA, van Krieken JH: Endothelial cell chimerism after renal transplantation and vascular rejection. Lancet 2001;357:33-37.

\$3 Grimm PC, Nickerson P, Jeffery J, Savani RC, Gough J, McKenna RM, Stern E, Rush DN: Neointimal and tubulointerstitial infiltration by recipient mesenchymal cells in chronic renal-allograft rejection. $\mathrm{N}$ Engl J Med 2001;345:93-97.

94 Kang DH, Kanellis J, Hugo C, Truong L, Anderson S, Kerjaschki D, Schreiner GF, Johnson RJ: Role of the microvascular endothelium in progressive renal disease. J Am Soc Nephrol 2002;13:806-816.

\$5 Kang DH, Anderson S, Kim YG, Mazzalli M, Suga S, Jefferson JA, Gordon KL, Oyama TT, Hughes J, Hugo C, Kerjaschki D, Schreiner GF, Johnson RJ: Impaired angiogenesis in the aging kidney: Vascular endothelial growth factor and thrombospondin-1 in renal disease. Am J Kidney Dis 2001;37:601-611.

-96 Masuda Y, Shimizu A, Mori T, Ishiwata T, Kitamura H, Ohashi R, Ishizaki M, Asano G, Sugisaki Y, Yamanaka $\mathrm{N}$ : Vascular endothelial growth factor enhances glomerular capillary repair and accelerates resolution of experimentally induced glomerulonephritis. Am J Pathol 2001;159:599- 608.

-97 Reinders ME, Rabelink TJ, Briscoe DM: Angiogenesis and endothelial cell repair in renal disease and allograft rejection. J Am Soc Nephrol 2006;17:932-942.

\$98 Moulton KS, Vakili K, Zurakowski D, Soliman M, Butterfield C, Sylvin E, Lo KM, Gillies S, Javaherian K, Folkman J: Inhibition of plaque neovascularization reduces macrophage accumulation and progression of advanced atherosclerosis. Proc Natl Acad Sci USA 2003;100:4736-4741.

99 Reinders ME, Briscoe DM: Angiogenesis and allograft rejection. Graft 2002;5: 96-101.

100 Reinders ME, Sho M, Izawa A, Wang P, Mukhopadhyay D, Koss KE, Geehan CS, Luster AD, Sayegh MH, Briscoe DM: Proinflammatory functions of vascular endothelial growth factor in alloimmunity. J Clin Invest 2003;112:1655-1665.

101 Denton MD, Magee C, Melter M, Dharnidharka VR, Sayegh MH, Briscoe DM: TNP-470, an angiogenesis inhibitor, attenuates the development of allograft vasculopathy. Transplantation 2004;78:1218-1221.

102 Valujskikh A, Lantz O, Celli S, Matzinger P, Heeger PS: Cross-primed CD8(+) T cells mediate graft rejection via a distinct effector pathway. Nat Immunol 2002;3:844-851.

103 Sayegh MH, Carpenter CB: Role of indirect allorecognition in allograft rejection. Int Rev Immunol 1996;13:221-229.

104 Yang Z, Wang C, Yang S, Hong T, Wang F, Xia L, Wang C: Endothelial progenitor cells induce transplant arteriosclerosis via VEGFR-1/2 activity. Atherosclerosis 2015;238:26-32.

105 Burger D, Gutsol A, Carter A, Allan DS, Touyz RM, Burns KD: Human cord blood CD133+ cells exacerbate ischemic acute kidney injury in mice. Nephrol Dial Transplant 2012;27:3781-3789.

106 Sepp D, Esposito L, Zepper P, Ott I, Feurer R, Sadikovic S, Hemmer B, Poppert H: Surface expression of CXCR4 on circulating CD133 progenitor cells is associated with plaque instability in subjects with carotid artery stenosis. J Angiogenes Res 2009;1:10.

107 Rastogi P, White MC, Rickard A, McHowat J: Potential mechanism for recruitment and migration of CD133 positive cells to areas of vascular inflammation. Thromb Res 2008;123:258-266.

108 Bartunek J, Vanderheyden M, Vandekerckhove B, Mansour S, De Bruyne B, De Bondt P, Van Haute I, Lootens $\mathrm{N}$, Heyndrickx G, Wijns W: Intracoronary injection of CD133-positive enriched bone marrow progenitor cells promotes cardiac recovery after recent myocardial infarction: feasibility and safety. Circulation 2005;112:I178-1183.

109 Pizarro S, García-Lucio J, Peinado VI, Tura-Ceide O, Díez M, Blanco I, Sitges M, Petriz J, Torralba Y, Marín P, Roca J, Barberà JA: Circulating progenitor cells and vascular dysfunction in chronic obstructive pulmonary disease. PLoS One 2014;9:e106163. 


\section{Kidney \\ Blood Pressure Research}

Ozkok et al.: EPCs and Kidney Diseases

110 Flammer AJ, Gössl M, Widmer RJ, Reriani M, Lennon R, Loeffler D, Shonyo S, Simari RD, Lerman LO, Khosla S, Lerman A: Osteocalcin positive CD1331/CD342/KDR1 progenitor cells as an independent marker for unstable atherosclerosis. Eur Heart J 2012;33:2963-2969.

111 Mizrak D, Brittan M, Alison MR: CD133: molecule of the moment. J Pathol 2008;214:3-9.

112 Stamm C, Kleine HD, Choi YH, Dunkelmann S, Lauffs JA, Lorenzen B, David A, Liebold A, Nienaber C, Zurakowski D, Freund M, Steinhoff G: Intramyocardial delivery of CD133+ bone marrow cells and coronary artery bypass grafting for chronic ischemic heart disease: safety and efficacy studies. J Thorac Cardiovasc Surg 2007;133:717-725.

113 Bakondi B, Shimada IS, Perry A, Munoz JR, Ylostalo J, Howard AB, Gregory CA, Spees JL: CD133 identifies a human bone marrow stem/progenitor cell sub-population with a repertoire of secreted factors that protect against stroke. Mol Ther 2009;17:1938-1947.

114 Ozkok A, Atas R, Cinar SA, Yilmaz A, Aktas E, Deniz G, Yildiz A: CD133+ cells are associated with adipocytokines and endothelial dysfunction in hemodialysis patients. BMC Nephrol 2017; 26;18:250.

115 Kong D, Melo L, Mangi A, Zhang L, Lopez- Ilasaca M, Perrella MA, Liew CC, Pratt RE, Dzau VJ: Enhanced inhibition of neointimal hyperplasia by genetically engineered endothelial progenitor cells. Circulation 2004;109:1769-1775.

116 Murasawa S, Llevadot J, Silver M, Isner J, Losordo D, Asahara T: Constitutive human telomerase reversetranscriptase expression enhances regenerative properties of endothelial progenitor cells. Circulation 2002;106: 1133-1139.

117 Di Stefano V, Cencioni C, Zaccagnini G, Magenta A, Capogrossi M, Martelli F: p66ShcA modulates oxidative stress and survival of endothelial progenitor cells in response to high glucose. Cardiovasc Res 2009;82:421-429.

118 Seeger F, Chen L, Spyridopoulos I, Altschmied J, Aicher A, Haendeler J: Downregulation of ETS rescues diabetes-induced reduction of endothelial progenitor cells. PLoS One 2009;4:e4529.

119 Kupatt C, Hinkel R, Lamparter M, von Brühl ML, Pohl T, Horstkotte J, Beck H, Müller S, Delker S, Gildehaus FJ, Büning H, Hatzopoulos AK, Boekstegers P: Retroinfusion of embryonic endothelial progenitor cells attenuates ischemia-reperfusion injury in pigs: role of phosphatidylinositol 3-kinase/AKT kinase. Circulation 2005;112:I117-I122.

120 Wei J, Blum S, Unger M, Jarmy G, Lamparter M, Geishauser A, Vlastos GA, Chan G, Fischer KD, Rattat D, Debatin KM, Hatzopoulos AK, Beltinger C: Embryonic endothelial progenitor cells armed with a suicide gene target hypoxic lung metastases after intravenous delivery. Cancer Cell 2004;5:477-488.

121 Ratliff BB, Goligorsky MS: Delivery of EPC embedded in HA-hydrogels for treatment of acute kidney injury. Biomatter 2013;3.

122 Ratliff BB, Ghaly T, Brudnicki P, Yasuda K, Rajdev M, Bank M, Mares J, Hatzopoulos AK, Goligorsky MS: Endothelial progenitors encapsulated in bioartificial niches are insulated from systemic cytotoxicity and are angiogenesis competent. Am J Physiol Renal Physiol 2010;299:F178-F186.

123 Wang X, Yu Y, Li M, Alkhawaji A, Chen C, Liu X, Jiang J, Zhang J, Wang Z, Li T, Zhang W, Mei J: EPCs enhance angiogenesis in renal regeneration. Oncotarget 2016;19;7:44941-44949.

124 Akita T, Murohara T, Ikeda H, Sasaki K, Shimada T, Egami K, Imaizumi T: Hypoxic preconditioning augments efficacy of human endothelial progenitor cells for therapeutic neovascularization. Lab Invest 2003;83:6573.

125 Rehman J, Li J, Parvathaneni L, Karlsson G, Panchal VR, Temm CJ, Mahenthiran J, March KL: Exercise acutely increases circulating endothelial progenitor cells and monocyte-/macrophage-derived angiogenic cells. J Am Coll Cardiol 2004;43:2314-2318.

126 Valgimigli M, Rigolin GM, Fucili A, Porta MD, Soukhomovskaia O, Malagutti P, Bugli AM, Bragotti LZ, Francolini G, Mauro E, Castoldi G, Ferrari R: CD34+ and endothelial progenitor cells in patients with various degrees of congestive heart failure. Circulation 2004;110:1209-1212.

127 Shintani S, Murohara T, Ikeda H, Ueno T, Honma T, Katoh A, Sasaki K, Shimada T, Oike Y, Imaizumi T: Mobilization of endothelial progenitor cells in patients with acute myocardial infarction. Circulation 2001;103:2776-2779.

128 Taguchi A, Matsuyama T, Moriwaki H, Hayashi T, Hayashida K, Nagatsuka K, Todo K, Mori K, Stern DM, Soma T, Naritomi H: Circulating CD34-positive cells provide an index of cerebrovascular function. Circulation 2004;109:2972-2975. 


\section{Kidney \\ Blood Pressure Research}

Ozkok et al.: EPCs and Kidney Diseases

129 Takahashi T, Kalka C, Masuda H, Chen D, Silver M, Kearney M, Magner M, Isner JM, Asahara T: Ischemia and cytokine-induced mobilization of bone marrow-derived endothelial progenitor cells for neovascularization. Nat Med 1999;5:434-438.

130 Gill M, Dias S, Hattori K, Rivera ML, Hicklin D, Witte L, Girardi L, Yurt R, Himel H, Rafii S: Vascular trauma induces rapid but transient mobilization of VEGFR2+ AC133+ endothelial precursor cells. Circ Res 2001;88:167-174.

131 Xue J, Qin Z, Li X, Cao P, Jia R: Protective Effects of Ischemic Preconditioning-Mediated Homing of Endothelial Progenitor Cells on Renal Acute Ischemia and Reperfusion Injury in Male Rats. Ann Transplant 2017:7;22:66-74.

132 Dimmeler S, Aicher A, Vasa M, Mildner-Rihm C, Adler K, Tiemann M, Rütten H, Fichtlscherer S, Martin H, Zeiher AM: HMG-CoA reductase inhibitors (statins) increase endothelial progenitor cells via the PI 3-kinase/Akt pathway. J Clin Invest 2001;108:391-397.

133 Min TQ Zhu CJ, Xiang WX, Hui ZJ, Peng SY: Improvement in endothelial progenitor cells from peripheral blood by ramipril therapy in patients with stable coronary artery disease. Cardiovasc Drugs Ther 2004;18:203-209.

134 Bahlmann FH, de Groot K, Mueller O, Hertel B, Haller H, Fliser D: Stimulation of Endothelial Progenitor Cells: A New Putative Therapeutic Effect of Angiotensin II Receptor Antagonists. Hypertension 2005;45:526-529.

135 Wang CH, Ciliberti N, Li SH, Szmitko PE, Weisel RD, Fedak PW, Al-Omran M, Cherng WJ, Li RK, Stanford WL, Verma S: Rosiglitazone facilitates angiogenic progenitor cell differentiation toward endothelial lineage: a new paradigm in glitazone pleiotropy. Circulation 2004;109:1392-1400.

136 Fadini GP, Boscaro E, Albiero M, Menegazzo L, Frison V, de Kreutzenberg S, Agostini C, Tiengo A, Avogaro A: The oral dipeptidyl peptidase-4 inhibitor sitagliptin increases circulating endothelial progenitor cells in patients with type 2 diabetes: possible role of stromal-derived factor-1alpha. Diabetes Care 2010; 33:16071609.

137 Kalka C, Masuda H, Takahashi T, Gordon R, Tepper O, Gravereaux E, Pieczek A, Iwaguro H, Hayashi SI, Isner JM, Asahara T: Vascular endothelial growth factor(165) gene transfer augments circulating endothelial progenitor cells in human subjects. Circ Res 2000;86:1198-1202.

138 Nykanen AI, Krebs R, Saaristo A, Turunen P, Alitalo K, Ylä-Herttuala S, Koskinen PK, Lemström KB: Angiopoietin-1 protects against the development of cardiac allograft arteriosclerosis. Circulation 2003;107:1308-1314.

139 De Falco E, Porcelli D, Torella AR, Straino S, Iachininoto MG, Orlandi A, Truffa S, Biglioli P, Napolitano M, Capogrossi MC, Pesce M: SDF-1 involvement in endothelial phenotype and ischemia-induced recruitment of bone marrow progenitor cells. Blood 2004;104:3472-3482.

140 Ishizawa K, Kubo H, Yamada M, Kobayashi S, Suzuki T, Mizuno S, Nakamura T, Sasaki H: Hepatocyte growth factor induces angiogenesis in injured lungs through mobilizing endothelial progenitor cells. Biochem Biophys Res Commun 2004;324:276-280.

141 Patschan D, Hildebrandt A, Rinneburger J, Wessels JT, Patschan S, Becker JU, Henze E, Krüger A, Müller GA: The hormone melatonin stimulates renoprotective effects of "early outgrowth" endothelial progenitor cells in acute ischemic kidney injury. Am J Physiol Renal Physiol 2012;302:F1305-1312.

-142 Scheubel RJ, Zorn H, Silber RE, Kuss O, Morawietz H, Holtz J, Simm A: Age dependent depression in circulating endothelial progenitor cells in patients undergoing coronary artery bypass grafting. J Am Coll Cardiol 2003;42:2073-2080.

143 Chen JZ, Zhu JH, Wang XX, Xie XD, Sun J, Shang YP, Guo XG, Dai HM, Hu SJ: Effects of homocysteine on number and activity of endothelial progenitor cells from peripheral blood. J Mol Cell Cardiol 2004;36:233239.

-144 Grisar J, Aletaha D, Steiner CW, Kapral T, Steiner S, Seidinger D, Weigel G, Schwarzinger I, Wolozcszuk W, Steiner G, Smolen JS: Depletion of endothelial progenitor cells in the peripheral blood of patients with rheumatoid arthritis. Circulation 2005;111:204-211.

-145 Kondo T, Hayashi M, Takeshita K, Numaguchi Y, Kobayashi K, Iino S, Inden Y, Murohara T: Smoking cessation rapidly increases circulating progenitor cells in peripheral blood in chronic smokers. Arterioscler Thromb Vasc Biol 2004; 24:1442-1447. 


\section{Kidney Blood Pressure Research}

146 Butzal M, Loges S, Schweizer M, Fischer U, Gehling UM, Hossfeld DK, Fiedler W: Rapamycin inhibits proliferation and differentiation of human endothelial progenitor cells in vitro. Exp Cell Res 2004;300:6571.

147 Hung SC, Kuo KL, Huang HL, Lin CC, Tsai TH, Wang CH, Chen JW, Lin SJ, Huang PH, Tarng DC: Indoxyl sulfate suppresses endothelial progenitor cell-mediated neovascularization. Kidney Int 2016;89:574-585.

148 Zhu JZ, Zhang J, Yang K, Du R, Jing YJ, Lu L, Zhang RY: P-cresol, but not p-cresylsulphate, disrupts endothelial progenitor cell function in vitro. Nephrol Dial Transplant 2012;27:4323-4330.

149 Thum T, Tsikas D, Stein S, Schultheiss M, Eigenthaler M, Anker SD, Poole-Wilson PA, Ertl G, Bauersachs J: Suppression of endothelial progenitor cells in human coronary artery disease by the endogenous nitric oxide synthase inhibitor asymmetric dimethylarginine. J Am Coll Cardiol 2005;46:1693-1701.

150 Chen J, Xavier S, Moskowitz-Kassai E, Chen R, Lu CY, Sanduski K, Špes A, Turk B, Goligorsky MS: Cathepsin cleavage of sirtuin 1 in endothelial progenitor cells mediates stress-induced premature senescence. Am J Pathol 2012;180:973-983. 